\title{
DO TURKISH STUDENT TEACHERS FEEL READY FOR ONLINE LEARNING IN POST-COVID TIMES? A STUDY OF ONLINE LEARNING READINESS
}

\author{
Dr. Alev ATES-COBANOGLU \\ ORCID: 0000-0002-8319-9822 \\ Faculty of Education \\ Ege University \\ Izmir, TURKEY \\ Ilker COBANOGLU \\ ORCID: 0000-0002-9076-9678 \\ Faculty of Education \\ Ege University \\ Izmir, TURKEY
}

Received: 13/09/2020 Accepted: 22/01/2021

\begin{abstract}
The purpose of this descriptive study is to investigate on-line learning readiness levels of student teachers according to several variables. By using purposive sampling method, the sample consisted of 270 (200 female and 70 male) student teachers in Turkey. Data collection tools include (i) Student Demographics Form with 18 items, (ii) On-line Learning Readiness Scale with 18 items and five factors. Statistically, the quantitative data were analyzed via ANOVA, t-test and ANCOVA. The findings suggest that mean of on-line learning readiness levels of student teachers is at good level. On-line learning readiness levels of student teachers are significantly different according to their departments $[F(4,265)=3.450, p=0.09]$. Namely, the mean scores for the students from Elementary Education and Pre-school Education departments were significantly higher than those from Social Science Education department. Besides, student teachers who has Internet access had higher on-line learning readiness scores $(M=67.27, S D=9.86)$ than did those without access $(M=60.14$, $\mathrm{SD}=10.64), \mathrm{t}(268)=3.16, \mathrm{p}=.002$. There are also significant differences between student teachers' on-line learning readiness scores per their perceived information and communication technology use competency and departments after differences in accessibility to the Internet is controlled $(\mathrm{p}<.001)$. As mentioned by International Society for Technology in Education in 2019 standards, on-line learning readiness needs to be considered in detail to assist learners in using digital media in 21st century for learning; teaching; gathering, producing, sharing information for educational purposes. In conclusion, it is suggested that practitioners should increase online, distance or blended (both on-line and face-to-face) learning experiences of their students who are prospective teachers of the 21 st century learners. Therefore, it is strongly suggested contributing development of learning and teaching skills of student teachers by getting them more familiar with on-line learning environments especially in post-Covid times.
\end{abstract}

Keywords: Online learning readiness, student teachers, distance learning, distance education.

\section{INTRODUCTION}

$21^{\text {st }}$ century learning requires teachers have growth rather than fixed mindsets which are best adapted to the significant changes in learning, since they teach students the future with the knowledge that it is unknown yet filled with possibilities (Faulkner and Latham, 2016). This statement implies a critical requirement for future teachers as having growth mindsets since life and skills for surviving in the future constantly evolve. For example, information and communication technology (ICT) have grave impacts on the way we learn and teach in teacher training specifically. With the help of the advances in ICT, distance learning especially 
online distance learning is becoming pervasive worldwide. As Li and Lalani (2020) implies, the overall online education market projected to reach $\$ 350$ Billion by 2025 .

Among plethora of definitions, online learning in this paper refers to learning that is mediated by the Internet (Rapanta, Botturi, Goodyear, Guàrdia and Koole, 2020). The popularity of online learning enormously increased by the novel Coronavirus. The Covid-19 pandemic around the world caused many schools shut down and so over 1.2 billion children are out of the classroom ( $\mathrm{Li}$ and Lalani, 2020). In these post-Covid times, online learning offers learners and teachers accessibility, flexibility, self-paced and customized learning facilities and interaction in educational settings so the increasing number of online courses and students at institutions of higher education is remarkable nowadays (Tsai, 2020; Wei and Chou, 2020). So, the prospective teachers need to possess essential knowledge and skills for the 21 st century to raise the new generation who are born in a digital world. But, do the prospective teachers themselves ready for online distance learning? Are they ready to make use of digital learning environments effectively? The answers to these questions are more vital especially in these post-Covid pandemic times with more emphasis on online and blended learning. We think that online distance learning seems to be the only safest way out in these post-Covid days. Joosten and Cusatis (2020) suggest that the antecedent variables such as student characteristics need to be refocused for online learning success. Also, Bovermann, Weidlich and Bastiaens (2018) imply that designing learning environments which consider online learning readiness (OLR) and motivational factors of students is a challenge for instructors. Therefore, present study focuses on explaining some of the variables for OLR for successful results in online learning and teaching experiences.

There are many studies related to OLR of higher education students in several countries and the variables which effect OLR. For example, Afolabi (2015) studied available online learning tools and OLR at a university in Nigeria. The findings revealed the availability of online learning tools and readiness of both the students and the staff for online learning practices whenever they put into effect. A study of Matanaghi (2015) from Eastern Mediterranean University, North Cyprus showed that online readiness levels of student teachers are relatively high and there is no significant difference in OLR according to their fields. In his dissertation Cavusoglu (2019) studied the relations between online and self-directed learning readiness of college students and industry professionals. And he came up with significant and positive correlations between those variables. He suggested a cross-cultural study to reveal if cultural differences exist with self-directed and OLR. Also, he suggested comparing online and self-directed learning readiness of students, who enrolled only in online courses and those only in traditional courses. Ramadhanu, Putra, Syahputra, Arsyah \& Sari (2019) examined learning satisfaction, OLR, learning culture and character strength of university students in Indonesia. Their findings indicated that learning culture, character strength and learning satisfaction significantly effect OLR. In another study, Wei and Chou (2020) investigated the relations between online learning perceptions, OLR, online learning performance and course satisfaction of higher education students. They found out that computer/Internet self-efficacy for OLR possesses a mediated effect on both online learning perceptions and online discussion score and on online learning perceptions and course satisfaction.

Moreover, studies related to OLR of Turkish preservice teachers also exist - e.g. Horzum, Kaymak and Gungoren (2015) investigated the relations between OLR, academic motivation, and perceived learning of university students who experienced online learning. They found out that online-learning readiness directly predicted academic motivation while indirectly predicted perceived learning and suggested that practitioners should increase readiness for higher motivation for learning. Demiralay, Bayir, \& Gelibolu (2016) investigated the relations between personal innovativeness and readiness for online learning. It was their claim that the higher students' personal innovativeness is the higher adaptation which occurs for online learning. And they revealed that there is a positive correlation between readiness for online learning and personal innovativeness at medium level. Also, Kuleli (2018) studied the pre-service teachers' readiness level for online learning and computational thinking skills. Her findings indicated that pre-service teachers considered themselves sufficient in general OLR and a significant difference was found in general OLR and in sub-dimensions like computer and internet selfefficacy and learner control among departments, and it was English Language Teaching students that showed the highest readiness level in these sub-dimensions and in the general scale.

Although these studies give insight about OLR and some of the related variables, there is a lack of comparison of OLR of student teachers according to department, having Internet access and further analysis related to Internet access. It is considered to be vital for investigating OLR of student teachers and some underlying factors especially during Covid-19 pandemic since remote online learning is inevitable for many schools and 
universities which have been affected by the pandemic at various levels worldwide. Besides, it is considered that online learning readiness studies are of great importance both before and after Covid-19 for designing quality online instruction in the digitalized world. Therefore, present study investigates following research questions:

1. What is the level of online learning readiness of students?

2. Does on-line learning readiness of student teachers significantly differ according to their departments?

3. Does on-line learning readiness of student teachers significantly differ according to their accessibility to the Internet?

4. If we control for differences in student teachers' accessibility to the Internet, does their on-line learning readiness significantly differ according to their departments?

5. If we control for differences in student teachers' accessibility to the Internet, does their on-line learning readiness significantly differ according to their perceived ICT use competency?

\section{METHOD}

In this descriptive study, the researchers conducted a survey to investigate on-line learning readiness of student teachers. Cohen, Manion \& Morrison (2007) reports that descriptive research is used to describe characteristics of the phenomenon being studied or to define the relationship between phenomenon.

\section{Participants}

Purposeful sampling technique is applied for selecting the study group. About purposeful sampling, Emmel (2013) notes that the researcher decides how to use the sampling strategy and the issues he/she consider have central importance in that decision-making. In present study, freshman students of educational faculty were selected as the study group since it would be possible to design instruction according to the results of current study in the following few years of them before graduation. The student teachers who enrolled in the Information Technology course in Spring semester took part in the survey. The participants of the study are intentionally selected from departments other than Computer Education and Instructional Technology (CEIT) since the students at CEIT departments are taking courses for online learning-teaching, ICT integration, effective ICT use, digital material design and so on (Council of Higher Education, 2018). So, the study group included 270 student teachers (200 female, 70 male) from five departments of Ege University, Faculty of Education located in Izmir which is at the west coast of Turkey. Their demographics and some preferences for learning are shown in Table 1.

Table 1. Demographics of the study group $(n=270)$

\begin{tabular}{|c|c|c|c|c|c|}
\hline Variable & f & $\%$ & Variable & $f$ & $\%$ \\
\hline \multicolumn{6}{|l|}{ Department } \\
\hline Pre-school Education & 54 & 20.0 & \multirow{2}{*}{ Owning Internet access } & & \\
\hline Guidance \& Counseling & 55 & 20.4 & & \multirow{2}{*}{249} & \multirow{2}{*}{92.2} \\
\hline Elementary Education & 57 & 21.1 & \multirow{2}{*}{$\begin{array}{l}\text { Yes } \\
\text { No }\end{array}$} & & \\
\hline Social Science Education & 55 & 20.4 & & 21 & 7.8 \\
\hline Turkish Education & 49 & 18.1 & & & \\
\hline \multirow{2}{*}{\multicolumn{3}{|c|}{ Gender }} & \multicolumn{3}{|l|}{ Perceived level of ICT use } \\
\hline & & & \multirow{3}{*}{$\begin{array}{l}\text { Insufficient } \\
\text { Moderate } \\
\text { Good }\end{array}$} & 45 & 16.6 \\
\hline remale & 200 & $\begin{array}{l}74.1 \\
250\end{array}$ & & 121 & 44.8 \\
\hline Male & 70 & 25.9 & & 104 & 38.5 \\
\hline \multicolumn{3}{|l|}{ GPA } & \multicolumn{3}{|l|}{ Age } \\
\hline 1.99 and below & 13 & 4.8 & \multirow{4}{*}{$\begin{array}{l}23 \text { and below } \\
24-26\end{array}$} & \multirow{2}{*}{69} & \multirow{2}{*}{25.6} \\
\hline $2.00-2.49$ & 68 & 25.2 & & & \\
\hline $2.50-2.99$ & 105 & 38.9 & & & \\
\hline 3.00 and above & 84 & 31.1 & & $8 /$ & 32.2 \\
\hline
\end{tabular}


Table 1 presents those participants are from five departments of the educational faculty. GPA as an indicator for academic background showed that $38.9 \%(n=105)$ has $2.50-2.99$ points. They perceive their ICT (PC and internet) use at moderate level. About technical facilities and capabilities, the study group mostly (44.8\%, $n=121$ ) perceive their ICT use at moderate level and $92.2 \%$ of them have Internet access.

\section{Data Collection and Analysis}

To investigate on-line learning readiness of student teachers, student demographics questionnaire and online learning readiness scale were administered.

\section{Student Demographics Questionnaire}

This questionnaire was developed by the researchers. It includes 18 items such as department, gender, having Internet access, perceived ICT use competency. And content validity of the questionnaire was checked by the three ICT education experts.

\section{On-Line Learning Readiness Scale}

On-line learning readiness (OLR) scale was developed by Yurdugul \& Alsancak Sarikaya (2013). It is the Turkish version of Online Learning Readiness Scale, which was originally developed by Hung, Chou, Chen \& Own (2010). The researchers conducted scale development in two stages: a) the development of the Turkish version of the scale with judgments of 13 experts of language and study domain, and b) the implementation of the scale with a total of 724 students from five different universities. It was found that the values of construct reliability and alpha reliability coefficients for the five subscales were acceptable which were higher 0.70 . In present study, alpha reliability coefficient for the overall scale was calculated as 0.88 .

In data analysis, demographic data of the sample was displayed via descriptive statistics such as frequency and percentage. The scale data was checked for normality assumption. As Leech, Barrett \& Morgan (2008) suggested, if the skewness is less than plus or minus one (which is -0.68 in this case), the variable (online learning readiness) is at least approximately normal. For the second research question, 1-way between subjects ANOVA (Analysis of Variance) and for the third one, independent samples t-test was performed.

For the fourth and fifth research questions, the following assumptions were checked to do ANCOVA (Analysis of Covariance), (a) independence of observations, (b) normal distribution of the dependent variable, (c) homogeneity of variances, (d) linear relationships between the covariates and the dependent variable, and (e) homogeneity of regression slopes. For the third research question, the assumption of homogeneity of variances was violated; however, because cell sizes were similar (54, 55, 57, 55 and 49), this violation did not present an issue as reported by Leech et al. (2008) and all other assumptions were met.

\section{The Competence of the Researchers}

The authors are both experienced in teaching computer education and instructional technology era. Both authors graduated Faculty of Education; the first from Computer Education and Instructional Technology (CEIT) program and the second from Computer Systems Education program. They both have ICT teaching experience at high schools over two years. The first author has 14 years of teaching at Department of Computer Education and Instructional Technology of Educational Faculty while the second one has 18. Regarding current study, both authors are instructors of the participant students who were enrolled Information Technology course. And they have been teaching that course for over 13 years. Academically, the first author has master's degree in CEIT program besides PhD degree in Curriculum and Instruction program, while the second one has Master degree in Curriculum and Instruction program. 


\section{FINDINGS}

What is the Level of Perceived Online Learning Readiness of Student Teachers?

Table 2. Descriptive statistics

\begin{tabular}{lccccc}
\hline & N & Min & Max & $\bar{X}$ & $S D$ \\
\hline OLR score & 270 & 26 & 88 & 66.71 & 10.087 \\
Valid N (listwise) & 270 & & & & \\
\hline
\end{tabular}

In Table 2, the minimum OLR score is 26 while maximum score is 88 . The mean score for perceived online learning readiness of the participants is at good level $(M=66.71, S D=10.087)$ in general. This finding posits that student teachers consider themselves sufficient for online learning.

\section{Does On-Line Learning Readiness of Student Teachers Significantly Differ according to Their Departments?}

A one-way between subjects ANOVA was conducted to compare the effect of department on on-line learning readiness of student teachers.

Table 3. One-way Analysis of Variance of online learning readiness by department

\begin{tabular}{lccccc}
\hline Source & $d f$ & $S S$ & $M S$ & $F$ & $p$ \\
\hline Between groups & 4 & 1354.56 & 338.64 & 3.45 & .009 \\
Within groups & 265 & 26014.48 & 98.17 & & \\
Total & 269 & 27369.04 & & & \\
\hline
\end{tabular}

As Table 3 presents, there was a significant effect of department on on-line learning readiness at the $p<.05$ level for the five conditions $[F(4,265)=3.450, p=0.09]$. Post hoc comparisons using the Tukey HSD test indicated that the mean score for the Pre-school Education department $(M=69.63, S D=9.89)$ was significantly different than Social Science Education department $(M=63.62, S D=13.18)$. Also, the Elementary Education department $(M=68.77, S D=8.45)$ was significantly higher from the Social Science Education department $(M=63.62, S D=13.18)$.

\section{Does On-Line Learning Readiness of Student Teachers Significantly Differ according to Their Accessibility to the Internet?}

An independent-samples t-test was conducted to compare on-line learning readiness in having Internet access and no Internet access conditions as shown in Table 4.

Table 4. t-Test results for comparing participants with and without Internet access on OLR

\begin{tabular}{|c|c|c|c|c|c|c|c|c|c|}
\hline & \multicolumn{6}{|c|}{ Internet access Opportunity } & \multirow{3}{*}{$\begin{array}{l}\text { 95\% Cl for Mean } \\
\text { Difference }\end{array}$} & & \\
\hline & \multicolumn{3}{|c|}{ Yes } & \multicolumn{3}{|c|}{ No } & & & \\
\hline & M & SD & $\mathrm{n}$ & M & SD & $\mathrm{n}$ & & $\mathrm{t}$ & $d f$ \\
\hline $\begin{array}{l}\text { Online Learning } \\
\text { Readiness }\end{array}$ & 67.27 & 9.86 & 249 & 60.14 & 10.64 & 21 & $2.69,11.57$ & $3.16^{*}$ & 268 \\
\hline
\end{tabular}

* $\mathrm{p}<.01$. 
Student teachers who have Internet access had higher on-line learning readiness scores $(M=67.27, S D=9.86)$ than did those with no Internet access $(M=60.14, S D=10.64), t(268)=3.16, p=.002$. These results suggest that accessibility to the Internet effects on-line learning readiness of student teachers.

\section{If We Control for Differences in Student Teachers' Accessibility to the Internet, Does Their On-Line Learning Readiness Significantly Differ according to Their Departments?}

An analysis of covariance was used to assess whether student teachers' on-line learning readiness significantly differ according to their departments after controlling for differences in student teachers' accessibility to the Internet. Table 3 presents the means and standard deviations for on-line learning readiness of student teachers from all departments, before and after controlling for accessibility to the Internet. Table 4 indicates that after controlling for differences in student teachers' accessibility to the Internet, there is a significant difference according to department, $F(4,264)=3.37, \mathrm{p}=0.01$, partial eta ${ }^{2}=.035$.

Table 5. Adjusted and unadjusted department variable means and variability for on-line learning readiness using accessibility to the Internet as a covariate

\begin{tabular}{lccccc}
\hline & \multicolumn{3}{c}{ Unadjusted } & \multicolumn{2}{c}{ Adjusted } \\
\hline & $\mathrm{N}$ & $\mathrm{M}$ & $\mathrm{SD}$ & $\mathrm{M}$ & $\mathrm{SE}$ \\
Pre-school Education & 54 & 69.63 & 9.89 & 69.60 & 1.33 \\
Guidance \& Counseling & 55 & 65.27 & 9.16 & 64.99 & 1.32 \\
Elementary Education & 57 & 68.77 & 8.45 & 68.84 & 1.29 \\
Social Science Education & 55 & 63.62 & 13.18 & 64.09 & 1.32 \\
Turkish Education & 49 & 66.20 & 7.79 & 65.95 & 1.40 \\
\hline
\end{tabular}

Table 6. Analysis of covariance for on-line learning readiness as a function of department, using accessibility to the Internet as a covariate

\begin{tabular}{lccccc}
\hline Source & $\mathrm{df}$ & $\mathrm{MS}$ & $\mathrm{F}$ & $\mathrm{p}$ & $\mathrm{eta}^{2}$ \\
\hline Accessibility to the Internet & 1 & 909.57 & 9.57 & $.002^{* *}$ & .035 \\
Department & 4 & 320.16 & 3.37 & $.010^{*}$ & .049 \\
Error & 264 & & & & \\
\hline
\end{tabular}

Note. ${ }^{*} p<.05,{ }^{* *} p<.01$

5- If we control for differences in student teachers' accessibility to the Internet, does their on-line learning readiness significantly differ according to their perceived ICT use competency?

An analysis of covariance was used to assess whether student teachers' on-line learning readiness significantly differ according to their perceived ICT use competency after controlling for differences in student teachers' accessibility to the Internet. Table 5 presents the means and standard deviations for on-line learning readiness of student teachers from all levels of perceived ICT use competency, before and after controlling for accessibility to the Internet. Table 6 indicates that after controlling for differences in student teachers' accessibility to the Internet, there is a significant difference, $F(2,266)=27.43, \mathrm{p}=0.00$, partial eta $^{2}=.017$.

Table 7. Adjusted and unadjusted perceived ICT use competency variable means and variability for online learning readiness using accessibility to the Internet as a covariate

\begin{tabular}{lccccc}
\hline & & \multicolumn{2}{c}{ Unadjusted } & \multicolumn{3}{c}{ Adjusted } \\
\hline Insufficient & $\mathrm{N}$ & $\mathrm{M}$ & $\mathrm{SD}$ & $\mathrm{M}$ & $\mathrm{SE}$ \\
Moderate & 45 & 58.69 & 9.64 & 59.04 & 1.36 \\
Good & 121 & 65.83 & 9.12 & 65.89 & 0.83 \\
\hline
\end{tabular}


Table 8. Analysis of covariance for on-line learning readiness as a function of perceived ICT use competency, using accessibility to the Internet as a covariate

\begin{tabular}{lccccc}
\hline Source & $d f$ & $M S$ & $F$ & $p$ & eta2 \\
\hline Accessibility to the Internet & 1 & 389.03 & 4.73 & $.031^{*}$ & .017 \\
Perceived ICT use competency & 2 & 2255.83 & 27.43 & $.000^{* *}$ & .171 \\
Error & 266 & & & & \\
\hline
\end{tabular}

Note. ${ }^{*} p<.05,{ }^{* *} p<.01$

\section{DISCUSSIONS AND CONCLUSION}

As the literature implies (Allen and Seaman, 2013; Howard, Tondeur, Siddiq and Scherer, 2020; Tsai, 2020; Wei and Chou, 2020) online learning gains much more popularity day by day all around the world especially in post-Covid 19 pandemic times. It is considered that online learning readiness of preservice teachers is critical for future teachers especially after Covid-19 pandemic forced decision-makers to shift to fully online distance learning practices for public health. To get more successful online learning-teaching results, Rohayani and Sharipuddin (2015) suggest measuring online learning readiness and developing strategies accordingly. So, present study focused on the variables for online learning readiness of student teachers.

The findings for the first research question which is related to OLR levels of student teachers in general indicated perceived sufficiency is in consistent with recent related studies (Afolabi, 2015; Kuleli, 2018; Matanaghi, 2015). Another study which was conducted in rural Thai showed that the students' level of acceptance was only slightly more than neutral (Ngampornchai and Adams, 2016). In present study the pre-service teachers considered themselves sufficient for online learning readiness in general. However, their readiness scores do not posit an excellent readiness level which indicates that teacher educators need to find ways to increase the level of online learning readiness of student teachers.

For the second research question, the effect of department on on-line learning readiness of student teachers is investigated and significant differences are reported. The scores of the participants from Pre-school Education department and Elementary Education department are found to be significantly higher than Social Science Education department. A study by Kuleli (2018) also revealed significant differences according to departments indicating that English Language Teaching students showed the highest readiness level in these sub-dimensions and in the general scale. On the other hand, Matanaghi (2015) reported no significant difference among fields. Therefore, it is considered that the differences in the study need further investigation for underlying reason(s). The authors suggest researchers to study entry scores, personal interests, and background for online learning tendencies of the students in relation with OLR.

The third research question is related to the effect of accessibility to the Internet on on-line learning readiness of student teachers and the results suggest that when student teachers have Internet access, their perceived on-line learning readiness increases. Many OLR studies also support that finding - e.g. Koo (2008) found out that insufficient access to technology such as computer and internet is one of impediments to online collaborative learning as perceived by the teachers. Wei and Chou (2020) found out students with higher and positive online learning perception (e.g., perceived ease of loading in online courses, perceived accessibility of online learning resources) were readier to participate in online courses. Firat and Bozkurt (2020) also found out statistically significant correlation between the time spent online and online learning readiness. Similarly, many studies concluded that the success of e-learning adoption highly depends on technological accessibility and having a good Internet connection (Al-Asmari and Rabb Khan, 2014; Sarsar, Kaval, Klasser and Guneri, 2016).

The fourth research question aims to assess whether student teachers' on-line learning readiness significantly differ according to their departments after controlling for differences in student teachers' accessibility to the Internet. The findings indicated that a significant difference between student teachers per their departments remains after differences in accessibility to the Internet are controlled. And for the 
fifth and last research question, the researchers investigated to assess whether student teachers' on-line learning readiness significantly differs according to their perceived ICT use competency after controlling for differences in student teachers' accessibility to the Internet. And a significant difference is found between student teachers per their perceived ICT use competency after differences in accessibility to the Internet are controlled $(\mathrm{p}<.001)$. That means, even if we provide Internet access for all student teachers, there can still exist significant differences in online learning readiness of student teachers according to department and ICT use competency. Wei and Chou (2020) also found out that computer/Internet selfefficacy for online learning readiness possesses a mediated effect.

Online learning is fast becoming a significant constituent of higher education (Allen and Seaman, 2013) and it is becoming pervasive worldwide. Especially in these post-Covid times, online learning seems to be an option for students to continue education during the pandemic. As Daniel (2020) mentions, face-to-face instruction has been ceased for most students, requiring them to switch to online teaching in many countries. And one of the concerns of professionals is the level of online learning readiness of their students at that time (Allam et al., 2020). Therefore, current study focused on some of the variables and level of online learning readiness of freshman student teachers. They are prospective teachers of $21^{\text {st }}$ century learners who are born in a digitalized world. The findings indicated that mean of OLR levels of student teachers is at good level. OLR levels are significantly different according to their departments, namely, the mean scores for the students from Elementary Education and Preschool Education departments were significantly higher than those from Social Science Education department. Besides, student teachers who have Internet access had higher on-line learning readiness scores than did those without access. Also, there are significant differences between student teachers' OLR scores per their perceived ICT use competency and departments after differences in accessibility to the Internet are controlled.

Based on the results of this study, we formulated some recommendations as follows. For the researchers, further studies are recommended to reveal other significant factors on perceived online learning readiness and the ways to improve online learning readiness for increasing the number of online courses (Tsai, 2020; Wei and Chou, 2020) and success (Joosten and Cusatis, 2020; Kim, Hong and Song, 2019; Moftakhari, 2013). In e.g. Firat and Bozkurt (2020) reported a correlation between ODL (Open and Distance Learning) learners' preferred technological devices and their OLR; moreover they found out that smartphone use has a large effect on OLR. Such demographic factors can be investigated in further studies. Keeping in mind the Internet and computer technology access factor (Koo, 2008) related to on-line learning readiness, it is suggested that decision-makers find solutions for the students without Internet and computer technology access to increase their online learning capabilities and readiness.

Since current study is based on quantitative data, the researchers are encouraged to use qualitative and/ or mixed research designs as well to reflect different perspectives and experiences of the participants. Moreover, it is suggested instructional designers and practitioners to implement engaging online learning activities more often in their lessons for increasing OLR. Although the study is limited to freshman students in a Turkish educational faculty, the findings are considered to be helpful for comparing OLR of student teachers according to department, having Internet access and providing further analysis related to Internet access as a covariate variable. In these post-Covid times, online and blended learning offer great potential for continuing education worldwide which requires more attention and further studies for offering better on-line learning and teaching experiences. 


\section{BIODATA and CONTACT ADDRESSES of AUTHORS}

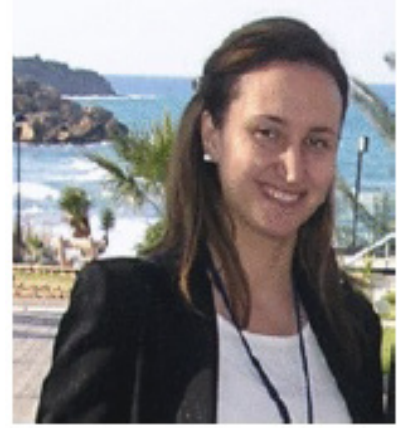

AlevATES-COBANOGLU is an Assistant Professor at Computer Education and Instructional Technology (CEIT) program of Faculty of Education, Ege University. She received her M.Sc. in CEIT from the Dokuz Eylul University in 2005. She had worked as an Information and Communication Technology (ICT) teacher at a high school of Ministry of National Education (MoNE) for three years. She received her $\mathrm{PhD}$ in Curriculum and Instruction from Ege University in 2013. Her academic interests are blended learning, ICT integration in education, instructional technology, and instructional design.

Alev ATES-COBANOGLU

Department of Computer Education and Instructional Technology,

Faculty of Education

Address: Ege University, 35040, Izmir, Turkey

Phone: +90232 3113144

E-mail: alev.ates@ege.edu.tr

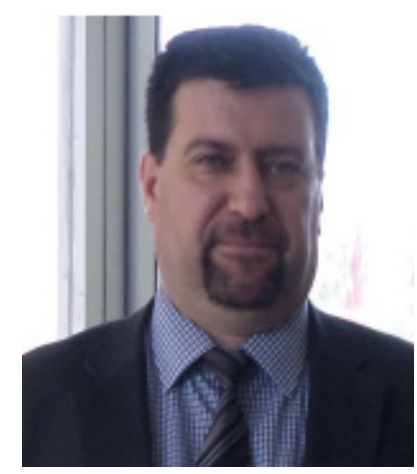

Illker COBANOGLU is a lecturer at Computer Education and Instructional Technology (CEIT) program of Faculty of Education, Ege University. He received his M.Sc. in Curriculum and Instruction from the Ege University in 2005. He had worked as an Information and Communication Technology (ICT) teacher at a high school of Ministry of National Education (MoNE) for two years. His academic interests are computer-assisted learning, teaching programming and instructional technology.

Ilker COBANOGLU

Department of Computer Education and Instructional Technology,

Faculty of Education

Address: Ege University, 35040, Izmir, Turkey

Phone: +90232 3114162

E-mail: ilker.cobanoglu@ege.edu.tr

\section{REFERENCES}

Al-Asmari, A.M. \& Rabb Khan, M.S. (2014). E-learning in Saudi Arabia: Past, present and future. Near and Middle Eastern Journal of Research in Education, 18, 2. doi: 10.5339/nmejre.2014.2

Allam, S. N. S., Hassan, M. S., Mohideen, R. S., Ramlan, A. F., \& Kamal, R. M. (2020). Online Distance Learning Readiness During Covid-19 Outbreak Among Undergraduate Students. International Journal of Academic Research in Business and Social Sciences, 10(5), 642-657.

Allen, I. E., \& Seaman, J. (2013). Changing course: Ten years of tracking online education in the United States. Wellesley: Babson College/Quahog Research Group.

Bovermann, K., Weidlich, J. \& Bastiaens, T. (2018). Online learning readiness and attitudes towards gaming in gamified online learning - a mixed methods case study. International Journal of Educational Technology in Higher Education, 15(27), 1-17. doi: 10.1186/s41239-018-0107-0

Cavusoglu, M. (2019). Online and Self-Directed Learning Readiness Among Hospitality and Tourism College Students and Industry Professionals. Unpublished doctoral dissertation. University of South Florida. Retrieved August 18, 2020 from https://scholarcommons.usf.edu/etd/7763 
Cohen, L., Manion, L., \& Morrison, K. (2007). Research methods in education. (6th Edition) London: Routledge-Falmer.

Council of Higher Education, (2018). Undergraduate program of computer education and instructional technology. Retrieved November 30, 2020 from https://www.yok.gov.tr/Documents/Kurumsal/ egitim_ogretim_dairesi/Yeni-Ogretmen-Yetistirme-Lisans-Programlari/Bilgisayar_ve_Ogretim_ Teknolojileri_Ogretmenligi_Lisans_Programi.pdf

Daniel, J. S. (2020). Education and the COVID-19 pandemic. Prospects. doi: 10.1007/s11125-020-09464-3

Demiralay, R., Bayir, E. A., \& Gelibolu, M. F. (2016). Investigation of relationship between students' personal innovativeness and readiness for online learning. Journal of Research in Education and Teaching, 5(1), 161-168.

Emmel, N. (2013). Sampling and Choosing Cases in Qualitative Research: A Realist Approach. London: SAGE Publications Ltd. doi: 10.4135/9781473913882

Faulkner, J., \& Latham, G. (2016). Adventurous Lives: Teacher Qualities for 21 st Century Learning. Australian Journal of Teacher Education, 41(4). doi: 10.14221/ajte.2016v41n4.9

Firat, M. \& Bozkurt, A. (2020) Variables affecting online learning readiness in an open and distance learning university.EducationalMediaInternational,57(2),112-127,doi: 10.1080/09523987.2020.1786772

Horzum, M. B., Kaymak, Z. D., \& Gungoren, O. C. (2015). Structural Equation Modeling Towards Online Learning Readiness, Academic Motivations, and Perceived Learning. Educational Sciences: Theory \& Practice, 15(3), 759-770.

Howard, S. K., Tondeur, J., Siddiq, F. \& Scherer, R. (2020). Ready, set, go! Profiling teachers' readiness for online teaching in secondary education. Technology, Pedagogy and Education, doi: 10.1080/1475939X.2020.1839543

Hung, M., Chou, C., Chen, C., \& Own, Z. (2010). Learner readiness for online learning: Scale development and student perceptions. Computers \& Education, 55, 1080-1090.

Joosten, T., \& Cusatis, R. (2020). Online Learning Readiness. American Journal of Distance Education, doi: $10.1080 / 08923647.2020 .1726167$

Kim, H. J., Hong, A. J. \& Song, H. D. (2019). The roles of academic engagement and digital readiness in students' achievements in university e-learning environments. International Journal of Educational Technology in Higher Education, 16(21), 1-18. doi: 10.1186/s41239-019-0152-3

Koo, A. C. (2008). Factors affecting teachers' perceived readiness for online collaborative learning: A case study in Malaysia. Educational Technology \& Society, 11(1), 266-278.

Kuleli, C. S. (2018). Evaluation of pre-service teachers' readiness level for online learning and computational thinking skills. Unpublished master thesis. Duzce University, Turkey.

Leech, N. L., Barrett, K. C., \& Morgan, G. A. (2008). SPSS for intermediate statistics. (3rd Edition) New York: Lawrence Erlbaum Associates.

Li, C. \& Lalani, F. (2020). The COVID-19 pandemic has changed education forever This is how. Retrieved August 22, 2020 from https://www.weforum.org/agenda/2020/04/coronavirus-education-globalcovid19-online-digital-learning/.

Matanaghi, A. (2015). Online Learning Readiness Level and Perceived Social Presence of The Teacher Candidate's in The Online Learning Environment an E.M.U Example. Unpublished Master Thesis. Eastern Mediterranean University, North Cyprus.

Moftakhari, M. M. (2013). Evaluating e-learning readiness of faculty of letters of Hacettepe. Unpublished Master thesis. Ankara: Hacettepe University.

Ngampornchai, A. \& Adams, J. (2016). Students' acceptance and readiness for E-learning in Northeastern Thailand. International Journal of Educational Technology in Higher Education, 13(34) doi: 10.1186/ s41239-016-0034-x 
Ramadhanu, A., Putra, R. B., Syahputra, H., Arsyah, R. H., \& Sari, D. P. (2019). Learning Satisfaction Analysis of Online Learning Readiness with Learning Culture and Character Strength as Antecedent Variables. Journal of Physics: Conference Series, 1339, International Conference Computer Science and Engineering (IC2SE), 26-27 April 2019, Padang, Indonesia.

Rapanta, C., Botturi, L., Goodyear, P., Guàrdia, L. \& Koole, M. (2020). Online University Teaching During and After the Covid-19 Crisis: Refocusing Teacher Presence and Learning Activity. Postdigital Science and Education. doi: 10.1007/s42438-020-00155-y

Rohayani, A. H., \& Sharipuddin, K. (2015). A literature review: Readiness factors to measuring e-Learning readiness in higher education. Procedia Computer Science, 59(2015), 230-234. https://doi. org/10.1016/j.procs.2015.07.564

Sarsar, F., Kaval, M.E., Klasser, G.D. \& Guneri, P. (2016). Impact of internet supported dental education: Initial outcomes in a study sample. J Human Sci., 13(3), 4986-4997.

Wei, H.C., \& Chou, C. (2020). Online learning performance and satisfaction: do perceptions and readiness matter? Distance Education, doi: 10.1080/01587919.2020.1724768

Yurdugul, H., \& Alsancak Sarikaya, D. (2013). The Scale of Online Learning Readiness: A Study of Validity and Reliability. Education and Science, 38 (169), 391- 406. 